\title{
Experience and Enlightenment of the Indian Buddhist Education
}

\author{
Poonam Kumari \\ School of Humanity and Law \\ Northeastern University \\ Shenyang, China
}

\author{
Wanbing Shi \\ School of Humanity and Law \\ Northeastern University \\ Shenyang, China
}

\begin{abstract}
Purpose: The aim of this paper is to discuss about the Indian Buddhist education in India and describe how it was developed and also talk about the experiences with reference to an advanced Buddhist education system in India. Design/methodology/approach: Based on the outstanding achievements made in developing Buddhist higher education in India, India has also made significant contributions to Buddhist education in the world. We analyze here the issues and the effects existing in Indian Buddhist education for development of Indian Buddhist research Universities. Findings: This paper also analyzes the different development experiences and references in India for Buddhist education. Originality/value: The main value of this paper is for the development of the Indian Buddhist higher education and spread these teaching and research aspects all over world. To the knowledge of the author, there has not been any scholarly research on this topic.
\end{abstract}

Keywords-Indian Buddhist education; experience; enlightenment

\section{INTRODUCTION}

As is well-known India, in ancient times, was a highly developed country, whose fame spread throughout the whole world due to its culture, religion, and higher education. Indian culture is the oldest and most developed and was well-known. Secondly, India's fame was also partly because it was a religion-oriented country. Apart from the most popular Hindu religion, many religions originated in India but the most developed among them is Buddhism, which also spread to other parts of the world such as China, Japan, Korea, Sri Lanka, Thailand, and Tibet, among others. It is often said that religion is the source of knowledge, and the word Buddha actually means wisdom. The third reason for Indian development is its higher education, and it is highly important to note that India has given the world the first University, viz., the Taxila University. [1]

One of the greatest contributions of Buddhism to India and the world was organizing a system of education. Before Lord Buddha, education was imparted in India by the Gurukula system, in which one individual teacher used to teach a group of students in his own ashram (home). The students were also staying with him. Impartment of education on a large scale was unknown till the advent of Buddhism, and since then education was transformed into an organized system. Thus, it can be claimed that, Buddhism laid the foundation for a new and special education system in ancient India and this played a very important role in the development of education not only in India, but in the whole world. There existed many centers of higher Buddhist learning in India long before western Universities came into existence. The higher Buddhist education and learning centers (in the form of monasteries) were established and protected by enlightened kings of India, who were ardent followers of Buddhism, who had a great respect for Buddhism. Generally these Buddhist Universities were set up with the only aim of developing Buddhist education. The Buddhist monks chose the life of meditation in forests, or the life of preaching Buddhist knowledge to people in monasteries and universities. [2]

\section{ENLIGHTENMENT OF THE INDIAN BUDDHIST EDUCATION}

There were many inequalities in the Indian society during the Buddha's time. All people were not considered equal; they were discriminated against on the basis of caste and only Brahminism dominated. The lower-caste people did not have the opportunity or right to get higher education. Thus, the reasons for the development of Buddhist education in India can be listed as follows:

\section{A. Equality Among People of All Classes}

According to Buddhist thinking, all people are equal in the world; there is neither religion nor castes for humans. In Buddha's time, students were considered for admission based on their varna (caste) and some of the Bramin teachers used to teach only the upper caste students. But, according to the Buddhist system, the students were selected based on the personal merits of the students and not on the basis of family background. Thus, all the Buddhist monks and nuns came from all castes, and as a result Buddhist education became popular in India.

\section{B. Pali Language}

At the time of Buddha, two languages were most prevalent in India; one was Sanskrit and the other was Pali. Sanskrit is the oldest language of India and it is considered the language of Gods. Before Lord Buddha, only Brahmins were the teachers and they were teaching mostly the upper 
caste students. The lower caste students were not allowed to study along with the upper caste students. The only duty of these lower caste people was to serve people who belonged to the upper castes. Accordingly, the common people did not know and use this language. Instead, they used Pali - the only common language in the society. Everything has changed after Lord Buddha, who decided to preach his dharma to common people in the common language of Pali. Thus, it is no exaggeration to say that Buddha had discovered a new India and opened the minds of common people to the benefits of education. This was the beginning of mass education in India, and perhaps in the world.

\section{Development of Indian Buddhist Education by Maintenance and Endowment}

India has contributed the most in the development of Buddhist education, through establishment of Buddhist monasteries by kings and businessmen of India. These Buddhist monasteries have subsequently become centers of higher learning of Buddhism.[1]

\section{Development of Indian Buddhist Education by Ancient Nalanda University}

The great ancient Nalanda Buddhist University was established in 427 A.D. by the great emperor Kumargupta I of Magadha dynasty. This was the only ancient university of higher education and center of learning in India (and perhaps the world), and continued to grow and develop from 427 to 1197 A.D. And Nalanda University was the next platform of development in the ancient Indian higher education system after the Gurukula education system. Nalanda University has earned an international status attracting a large number of students from other Asian countries and Europe by successfully received its objectives. Xuanzang wrote about the residential, library, classroom, and hostel facilities of the Nalanda University.

1) Residential: Nalanda University was wonderful and developed as the first residential university in the world. There were eight separate compounds, ten temples, big class rooms, and meditation halls at the Nalanda University.

2) Library: According to history of Nalanda University, the name was of main Dharma Gunj (the mountain of truth). And they had three big buildings as high as nine stores hall. The name was of libraries, Ratnododhi (sea of jewels), second Ratnasagar (ocean of pearl). They had hundred and thousand volumes in the library, and they had also subject text books on, for example, grammar, logic, literature, astrology, astronomy, and medicine.

3) Classrooms: As mentioned above, there were ten thousand students and nearly two thousand teachers living at the Nalanda University. Their class rooms were big, because there were one hundred students studying together in one class room. The most important fact was that no student left the class room until the class was over. The subjects studied were mostly philosophy, religion, Buddhism, and scientific thought in astronomy, mathematics, and anatomy, etc.
4) Hostel: They had a boarding system in the Nalanda University and the dormitory had three hundred rooms. The hostel was divided into three large floors. There were clear rules with the freshman students living on the first floor, the second level students lived on the second floor, and the senior students lived on the top floor. [3]

\section{EXPERIENCE OF INDIAN BUDDHIST EDUCATION}

Let us now look at some of the experiences of international scholars, who visited or studied at the Nalanda University.

\section{A. According to the Chinese Pilgrim Xuan Zang}

Nalanda University was the best higher education center for international scholars. According to history, there were ten thousand students and almost two thousand teachers living in the Nalanda University. Fahyan, the first Chinese scholar, visited this place in 410 A.D. Later, the famous Chinese pilgrim Xuan Zang (also called as Hiuen Tsang), visited India from 629 to 643 A.D., and studied in Nalanda in 637 A.D. during the reign of Magadha king Harshvardhan. Xuanzang mentioned that the education system in the Nalanda University was very powerful. The professors of Nalanda University were great scholars. Xuan Zang wrote that it was not easy for international students to get admission into the Nalanda University, and for good reasons. The first reason was, there was an entrance examination for admission, and the gatekeepers of Nalanda University, took the first examination. Let us imagine. if the gatekeepers of the Nalanda university were themselves scholars capable of examining the incoming students, then the many teachers would have been really great and eminent scholars. The second reason was, according to Xuan Zang, only 20\% of the international students were admitted based on the entrance and other examinations at Nalanda University.

\section{B. The Chinese Monk Yijing}

Who also came to the Nalanda University after Xuan Zang, wrote about the administration and decision-making process at the ancient Nalanda University. It was necessary that all issues were discussed in an assembly and that a consensus was required by all the members of the assembly; the members were mostly the resident Monks. For example, if any members had any business idea, then it was discussed with all the members of assembly. And the members of the assembly then ordered an officer to circulate this matter among all the members. Subsequently, all the resident members, one after another gave the report to the officer with folded hands. Even if a single member had any issue/reservation with the proposal, then this matter would not pass the assembly.[4][5][6]

\section{The PRESENT SituAtion OF BUdDhist EdUCATION}

Nava Nalanda Mahavihara University: In India, we currently have many institutions/universities teaching about Buddhist education as Buddhist Universities. One such institution is the Nava Nalanda Mahavihara University. 
Ven Bhikkhu Jagdish Kashyap presented a mind-blowing and superb idea of establishing a Buddhist Pali university to the first president of India, Dr. Rajendra Prasad. The President had welcomed the idea and declared that ancient center of Buddhist education of Nalanda University would be revived. Accordingly, the new university known as Nava Nalanda Mahivihara University Nava Nalanda Mahivihara University was established on November 20, 1951, and was situated opposite the old Nalanda University campus. From the beginning, the Nava Nalanda Mahivihara University has been following the great traditions of the ancient Nalanda University and Buddhist studies and Pali language continued to be taught in the new Nava Nalanda Mahavihara University. Subsequently, the Government of Bihar established a research institute called "Magadha Institute of Post Graduate Studies and Research in Pali and Allied Languages and Buddhist Education". The major goal of the Nava Nalanda Mahavihra University is to develop Buddhist education in the world similar to that in the ancient Nalanda University. On November 13, 2006, the University Grants Commission (UGC) of the Government of India recognized the Nava Nalanda Mahavihara university as a deemed university. [7]

\section{CONCLUSION}

As described above, India has made its significant contributions to the Buddhist education both in India and the world. It can be clearly seen that India gave the first Buddhist University, known as Nalanda University, to the world nearly 1600 years ago. Both Buddhist education Pali language have been developed by Nalanda University. Since the Pali language was used by the common people during the period of Buddha, the Buddhist education in India was developed through this language.

\section{REFERENCES}

[1] R.N. Sharma, R.K. Sharma. [History of education in India] [M] Atlantic Publishers and Distributors Pvt Ltd, 2004. Page no 39-53.

[2] J.C. Aggarwal. [Development of Education system in India] [M] Shipra publication, 2012 Revised Edition. paze no 41-51.(m).

[3] https://www.culturalindia.net/monuments/nalanda.html.

[4] Dutt, Sukumar. Buddhist Monks and Monasteries of India: Their History and Contribution to Indian Culture. London: George Allen and Unwin Ltd (Reprinted 1988). ISBN 81-208-0498-.

[5] www.vkmaheshwari.com/WP/?p=522.

[6] https://nalandauniversity.wordpress.com/about/.

[7] https://www.nnm.ac.in/. 